\title{
DOES GENDER INFLUENCE \\ THE INTERCULTURAL COMPETENCE (IC) OF INDONESIAN ENGLISH TEACHER?
}

\author{
(Apakah Gender Berpengaruh \\ terhadap Kompetensi Interkultural Guru Bahasa Inggris?)
}

\author{
Mas Muhammad Idris \\ Universitas Negeri Yogyakarta \\ Jalan Colombo No. 1, Karangmalang, Yogyakarta \\ Pos-el: masmuhammadidris@gmail.com
}

(Naskah Diterima 23 Februari 2021-Direvisi 11 Maret 2021-Disetujui 14 Maret 2021)

\begin{abstract}
Abstrak
Penelitian ini bertujuan untuk mengetahui kompetensi komunikasi antarbudaya (IC) guru bahasa Inggris dan menentukan apakah gender memengaruhinya. Penelitian ini dilakukan dengan alasan perlunya IC menjadi bagian penting dalam konteks pendidikan dan kehidupan ketika perubahan-perubahan pada masyarakat dalam hal komunikasi dan meningkatkan tujuan yang saling menguntungkan selalu terjadi. Penelitian ini adalah penelitain kuantitatif dalam bentuk survei. Sampel penelitian ini berjumlah 88 guru di Yogyakarta yang diambil menggunakan tabel Morgan (1970). Mereka diminta untuk menjawab sebuah instrumen yang telah diadaptasi yang terdiri atas 3 faktor dengan 40 butir pertanyaan. Instrumen ini dikembangkan oleh Pestalozzi Programme and Intercultural Cities of the Council of European Commission and the European Wergeland Centre (2008). Analisis mununjukkan bahwa tingkat IC guru bahasa Inggris dikategorikan tinggi dan tidak ada hubungan yang signifikan antara gender dan kompetensi interkultural guru bahasa Inggris. Dengan kata lain, gender tidak memengaruhi kemampuan IC mereka.
\end{abstract}

Kata kunci: kompetensi antarbudaya, guru bahasa Inggris, jenis kelamin

\begin{abstract}
This study is set out to see the intercultural competence (henceforth IC) degree of English teachers and determine whether gender influences their IC or not. This study is conducted due to the reason that the need of IC becomes essential part both in education and life context in which the societies' changes in communication and developing mutual aims have always been happened. This study was in the model of descriptive quantitative research that used a sample survey design. Samples of 88 English teachers in Yogyakarta taken by using Morgan's table (1970). They were asked to complete the instrument comprising 3 factors with 40 items developed by Pestalozzi Programme and Intercultural Cities of the Council of European Commission and the European Wergeland Centre (2008). This study revealed that the degree of IC of English teachers was high and there was no significant relationship between gender and the IC of English teachers. In other words, the gender does not influence their IC accordingly as well as it is recommended that the IC should be had by any individuals respectively.
\end{abstract}

Keywords: intercultural competence, English teacher, gender 


\section{INTRODUCTION}

In this discursive era the development of communication amongst people around the world has been noticed seriously since it presumably affects people's life and education who have a diverse background of cultures, languages, and nations, and their mutual goals with other individuals ((Idris, 2017, 2020); (Morganna R., Sumardi, \& Tarjana, 2020). This enhancement of communication indicates that those people have intercultural communication competence which should be always cultivated more and more. Added to this, Faerch \& Kasper (1983) argue that those people need communication strategy too as a plan to solve the problems once they face them in their intercultural encounter that can reach particular goals (as cited in Brown, 2007). In other words, the need of communication strategy as a way to overcome such problems becomes very important to the people who have a good intercultural communication competence, the author pinpoints, so that they can mingle with other people around the world easily using that communication strategy.

The term intercultural communication competence or, in short, intercultural competence (hereafter IC) is seen as an individual's capability to use the target language, for instance, English effectively and appropriately, Chen \& Starosta (1996) as cited in Idris (Idris M. M. \& Agus, 2019; Idris M. M. \& Ciptaningrum, 2018). They further emphasize that there are two things that constitute intercultural communicative competence namely effectiveness and appropriateness. The former is related to the capacity of an individual that makes any effect on his/her environment. While for the latter, it is more comprehensive than that of effectiveness. There are three abilities pertinent to the appropriateness in the process of communication. The first is the ability to understand that context may bind the talk so that the individual can communicate appropriately. Second, it is good to stay and keep away from inappropriate responses. Last, it is the ability to create a good atmosphere when conducting a communication via sharing feelings, informing as well as imagining something. In the same vein, Liddicoat \& Scarino (Liddicoat, A. J. \& Scarino, 2013) say that intercultural competence means that there is always interrelationship awareness between language and culture to attain good communication which later on, the misinterpretation of its meaning can be minimized. In short, it can be inferred that this intercultural competence (IC) is inevitable to be owned by any individual both in his/her life, and/or education. In other words, it is very important to have this competence since it can make people be open-minded and respect others through an intercultural context.

In the Indonesian context, Madya (Madya, 2013) argues that the Indonesian people have been naturally involving in the process of doing an intercultural interaction. It can be happened because of the multiculturalism condition that Indonesia has (Idris, 2020). Yet, there is still a possibility of misunderstanding and miscommunication conducted amongst them. The possibility might be occurred due to the differences of culture and gender of the people. Concerning culture and gender, according to Neculaesei (Neculaesei, 2015), she says that those two terms have mutual influences. The word culture in which language is always involved in it has a relationship towards communication and the agent or the doer of such communication can be in the form of a human. Human, she further argues, can be classified into gender (whether it is male or female), a social construct and determined by the society that has different roles which are the product of communication and at the same time they can influence communication. In other words, gender via its different roles can influence the communication made with others in society. Since intercultural communication includes culture and culture cannot be separated from language (Idris, 2017; Liddicoat A. J. \& Scarino, 2013; Morgana R. \& Anshori, 2018), it is then clear that the misconception may appear due to the utilization of language of the agent or the doer. To anticipate this condition, 
intercultural competence is needed to be implemented and owned by all people. However, not many people including English teachers in Indonesia show their high attention regarding this intercultural competence (Idris M. M. \& Agus, 2019). Therefore, this study is conducted to see the intercultural competence of English teachers and determine whether there is a significant relationship between the IC of English teachers and gender.

\section{Relationship between Culture and Language}

To define culture is a sort difficult. Culture has several definitions based on views of culturalist (Huber J. \& Reynolds, 2014; Liddicoat A. J. \& Scarino, 2010; Sun, 2013). Interestingly, from the notions of cultures, in the context of education, it is nice to see the perspective of Huber \& Reynolds (Huber J. \& Reynolds, 2014), they argue that the concept of culture is divided into three parts namely materials, social cultures, and subjective resources. To be more specific, the materials can be seen through tools, foods, and clothing. Meanwhile, the social cultures include for example language use, laws, religion, and cultural symbols. Lastly, the subjective resources, they are the people's beliefs, attitudes, values, norms, and discourses as well as practices through their daily life. Via all these parts as a concept of culture, any individual can be easily known.

About language use, the language is coined briefly by Liddicot, Papademetre, Scarino \& Kohler (Liddicoat A. J., Papademetre L., Scarino A. \& Kohler, 2003) who assure that it is a kind of conventional paradigm that can only be understood through a symbol system in the form of words that comes from sound arranged by syntax's rules. This concept sounds difficult to understand, yet if it is seen from Sun (Sun, 2013), it will be clearer. She says that language is a tool for conducting communication with other people. It is used to inform, chat, express, request, and perhaps persuade something that the point of it is to make someone understand what the communicators want. Since people communicate using the language in which it is part of the culture, then the relationship between culture and language is inevitable. This hindsight is supported by Kramsch (Kramsch, 2013), Liddicoat \& Scarino (Liddicoat A. J. \& Scarino, 2010) who argue that language and culture can be separated. In short, there is always a reciprocal relationship between culture and language.

\section{The Concept of Intercultural Competence (IC)}

The concept of intercultural competence (IC) is that it is the ability to use the combination of the elements of attitude, skill, knowledge which are applied in the process of intercultural activities, Huber \& Reynold as cited in Idris (Idris, 2020). In the same vein, Byram defines intercultural competence as an activity that is employed by individuals who can interact with people from different cultures, and nations using their language, skill to interpret and analyze cultural differences, also using their knowledge related to intercultural communication (Byram, 1997). Thus, it can be said that the main point of intercultural competence is that people who have a diverse background of cultures, languages, and even nations may use their ability of the compilation of attitude, skill, and knowledge to do an intercultural activity with other people. Henceforth, the people who own this competence should always be openminded so that they respect, and understand that their cultures are also others' cultures. Bennet adds to this that the people who have passed this competence can be categorized as interculturalist since they have good skill to ensure that the culture can be understood by other people through intercultural interaction (Bennet, 1993). Also, Vidiyanti \& Yulianto argue that in the Indonesian context, almost all people have this competence because Indonesia is a multicultural country (Vidiyanti M. O. \& Yulianto, 2019). 


\section{Relationship between Gender and Intercultural Competence}

Gender, based on Ceglarska, Li \& Chen, is an individual's type of psychology that regarded as either feminine or masculine (Ceglarska E. Li L. \& Chen, 2008). This definition can be synchronized with Neculaesei's view who said that gender can be categorized as male or female (Neculaesei, 2015). In other words, gender is a psychological type of human who can be labeled as either male or female. In relation to cultural beliefs, gender may include gender stereotype, and gender roles (Jonsen K., Maznevsji M. L., \& Schneider, 2010). It means that gender can make a bias of people's beliefs, perceptions, attitudes, and others (Wesarat P. O., Majid A. H., \& Sharif, 2016). Therefore, intercultural competence (IC) related to gender's hindsight is demanded to be owned by all people. Intercultural competence seems to be an integral part of every human's life for now and the future.

\section{METHODOLOGY}

The aim of this study was to determine the degree of Indonesian English teachers' IC and see whether the gender of the Indonesian English teachers influenced their IC or not. The sample of this study included 88 English teachers comprising $30.8 \%$ male and $46 \%$ female selected by using Morgan's table (1970). Moreover, the participants were taken from the first to the third grade English teachers. The data of this study were garnered through adapted questionnaire from the Pestalozzi Programme and the Intercultural Cities project of the Council of European Commission and the European Wergeland Centre (Lazar, 2008). This self-assessment tool was named Recognizing Intercultural Competence: What shows That I am Interculturally Competent? There were 40 items divided into three parts, 8 items for intercultural attitude, 22 items for intercultural knowledge, and 10 items for intercultural skill in the instruments and the participants were asked to assess their intercultural attitude, knowledge, and skill with 5 point scales (1 never, 2 - seldom, 3 - sometimes, 4 - often, 5 - always). All items were described in the form of I - statements and were in the form of the Indonesian language. This study used descriptive and Chi-Square tests to analyze the data with different procedures. The former was used as the first procedure to obtain the specific responses of the participants related to intercultural attitude, knowledge, and skill. While for the latter which was as the second procedure, it was used to gain whether the data, the gender, influenced the intercultural competence of the participants or not.

\section{DISCUSSIONS}

\section{The Degree of IC of English Teachers}

Pertaining to the first research problem, the findings related to the descriptive statistic revealed that the degree of IC of English teachers was seen as high with the mean score of 155.67 ( $\mathrm{SD}=15.924)$, (see Appendix 1). After that, the mean score was consulted to Table 1 to see whether the degree of IC of English teachers had a high intercultural competence (IC).

\section{Table 1}

Mean score of IC category

\begin{tabular}{cc}
\hline Mean Score & Category \\
\hline $\mathbf{x}>\mathbf{1 6 8}$ & Very High \\
\hline $\mathbf{1 3 6}<\mathbf{x} \leq \mathbf{1 6 8}$ & High \\
\hline $\mathbf{1 0 4}<\mathbf{x} \leq \mathbf{1 3 6}$ & Medium \\
\hline $\mathbf{7 2}<\mathbf{x} \leq \mathbf{1 0 4}$ & Low \\
\hline $\mathbf{x} \leq \mathbf{4 0}$ & Very Low \\
\hline
\end{tabular}

Moreover, the following chart expounds that there were 14 English teachers who had a "very high" degree of IC, 65 English teachers who had a "high" degree of IC, 8 English teachers who had a "moderate" degree of IC, 1 English teachers who had a "low" degree of IC, and none had a "very low" degree of IC. 


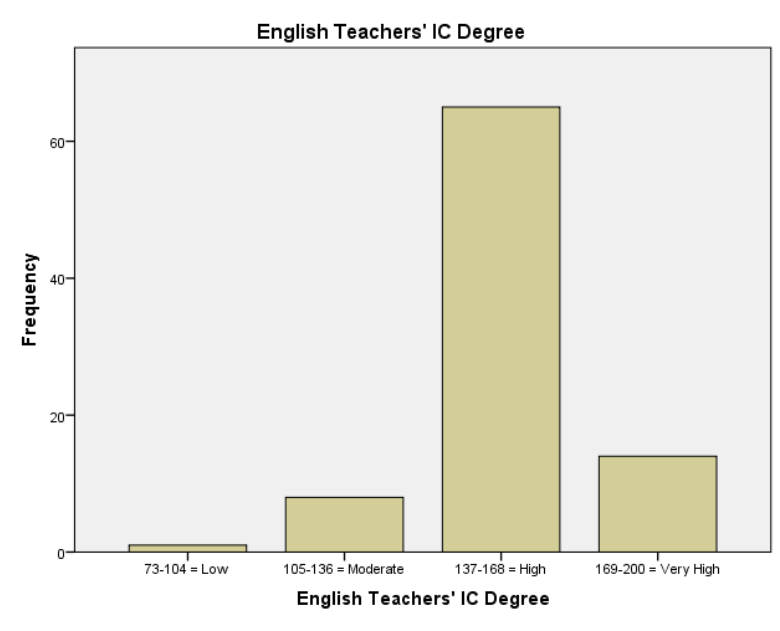

The finding of the second research question showed that sig. values .696 is bigger than 0.05 (see Table 2). It meant that there was no significant relationship between gender and English teachers. This also meant that this result did not confirm the alternative hypothesis (HI) in which there was a significant relationship between gender and English teachers. In other words, it meant that gender did not influence the intercultural competence (IC) of English teachers in Yogyakarta.

Table 2

The result of Chi-square tests Chi-Square Tests

\begin{tabular}{lccr}
\hline \multicolumn{4}{c}{ Chi-Square Tests } \\
\hline & Value & df & $\begin{array}{c}\text { Asymp. } \\
\text { Sig. (2- } \\
\text { sided) }\end{array}$ \\
\hline $\begin{array}{l}\text { Pearson Chi- } \\
\text { Square }\end{array}$ & $17.244^{\mathrm{a}}$ & 21 & .696 \\
\hline $\begin{array}{l}\text { Likelihood } \\
\text { Ratio }\end{array}$ & 21.197 & 21 & .447 \\
\hline $\begin{array}{l}\text { Linear-by- } \\
\text { Linear } \\
\text { Association }\end{array}$ & 1.669 & 1 & .196 \\
\hline $\begin{array}{l}\text { N of Valid } \\
\text { Cases }\end{array}$ & & & \\
\hline $\begin{array}{l}\text { a. } 44 \text { cells (100.0\%) have expected count } \\
\text { less than 5. The minimum expected count is } \\
\mathbf{4 0 .}\end{array}$ \\
\hline
\end{tabular}

The main point of this research is to see whether gender influences intercultural competence (IC) of English teachers in Yogyakarta. In this section, the author discusses those two results of the previous findings and relate them with the theory as well as some relevant studies.

The result of the first descriptive statistics tells that the English teachers in Yogyakarta obtain a high intercultural competence (IC) in which the elements of attitude, skill, and knowledge are in it (see Table 1). This result indicates that the English teachers in Yogyakarta have good behavior related to their activity towards other people who have different perspectives with them. English teachers can also be said that they have the ability to respect other people's culture (Altan, 2018). Moreover, the English teachers also show nice behavior pertinent to the proposed indicators namely attitude, skill, and knowledge. This means that the English teachers in Yogyakarta seem to implement or apply the three indicators in their process of teaching and learning in the classroom activity.

In addition, it seems that the English teachers are ready and not afraid to live and/or mingle with other people whom they do not recognize before. As Byram says that people who have intercultural competence, they can live meaningfully and culturally with others (Byram, 1997). Importantly, the English teachers seem to have an understanding well about cultural differences so that they can insert the elements of cultures into their intercultural talks (Hong, 2008; Huber J. \& Reynolds, 2014). Furthermore, the English teachers express their tolerance of ambiguity so that the essence of intercultural competence that involves respecting other people is employed respectively (Huber J. \& Reynolds, 2014).

Another finding which based on the result of the descriptive hypothesis revealed that there is no significant relationship between gender and English teachers in Yogyakarta. This means that the psychological types, male or female of the English teachers in Yogyakarta do not affect their intercultural competence (IC). They have the understanding related to the importance of having 
intercultural competence (IC) while they are conducting a teaching and learning process. Yet, the bias might be still appeared since the gender can make a bias of people's beliefs, perceptions, attitudes, and others (Wesarat P. O., Majid A. H., \& Sharif, 2016). Hence, the role of owning intercultural competence becomes very essential.

Furthermore, this result shows and confirms the null hypothesis in which there is clearly no different relationship significantly toward the intercultural competence of English teachers and their gender. This result contrasts with statements by scholars who said that gender, she emphasizes, can influence the attitude or behavior of people (Jonsen K., Maznevsji M. L., \& Schneider, 2010; Neculaesei, 2015; Wesarat P. O., Majid A. H., \& Sharif, 2016). Moreover, all the English teachers seem to have an adequate knowledge pertinent to intercultural competence (IC) so that they can deliver and insert the elements of IC such as attitude, knowledge, and skill into their teaching and learning process in the classroom.

\section{CONCLUSION}

This study has discussed the importance of intercultural competence (IC) that should be had by any individuals and English teachers in Yogyakarta specifically. Importantly, this study focuses on the degree of IC of English teachers in Yogyakarta and it shows that their intercultural competence (IC) is categorized as high which means that they are assumed that they are able to live culturally with other people and are able to teach as well as include several cultural elements into their process of teaching and learning. In other words, the degree of their IC reflects their high ability to understand cultural differences. Another conclusion of this study is that the gender whether it is male or female had by English teachers in Yogyakarta does not affect their degree of IC. Hence, it is meant that there is a great significant relationship between them, the gender and the high degree of intercultural competence (IC) of English teachers in
Yogyakarta. Finally, this study recommends that this intercultural competence (IC) is considered to be an integral part that should be owned by all people including English teachers in Indonesia.

\section{REFERENCES}

Altan, M. Z. (2018). Intercultural sensitivity: A study of pre-service English language teachers. Journal of Intercultural Communication, 46 (1), $1-17$.

Bennet, M. J. (1993). Towards ethnorelativism: A developmental model of intercultural sensitivity. In R. M. Paige (Ed.), Education for the intercultural experience (pp. 21-71). Yarmouth: Intercultural Press.

Brown, H. D. (2007). Principles of Language Learning and Teaching (5th ed.). New York: PearsonLongman.

Byram, M. (1997). Teaching and assessing intercultural communicative competence. Clevedon: Multilingual Matters.

Ceglarska, E., Li, L., \& Chen, K. (2008). How do culture and gender diversity impact.

Hong, S. (2008). The role of heritage students in incorporating culture into language teaching. South Asia Language Pedagogy and Technology, $1(1)$.

Huber, J., \& Reynolds, C. (2014). Developing intercultural competence through education. Paris: Council of Europe Publishing.

Idris, M. M., \& Agus, W. (2019). Intercultural communicative competence (ICC): What should Indonesian EFL teachers have related to ICC's elements? Journal of English Language Teaching and Linguistics, 4 (1), 67-76. https://doi.org/http://dx.doi.org/10.21 462/jeltl.v4i1.184

Idris, M. M., \& Ciptaningrum, D. S. (2018). 
Picture booklets to improve English speaking skills of slow learners. Early Childhood Research Journal, 1(1), 45-49.

https://doi.org/http//doi.org/10.23917/ ecrj.v1i1.6579

Idris, M. M. (2017). How to develop the competence of intercultural communication of non-English major Indonesian students. Proceeding International Conference on Islamic Education (ICIED)" Innovation, Approaches, Challenges, and the Future, 393-399.

Idris, M. M. (2020). Assessing intercultural competence (IC) of state junior high school English teachers in Yogyakarta. Indonesian Journal of Applied Linguistics, 9 (3), 628-636. https://doi.org/https://10.17509/ijal/v9 iv. 23213

Jonsen, K., Maznevsji, M. L., \& Schneider, S. C. (2010). Gender differences in leadership-believing is seeing: Implications for managing diversity. Equally, Diversity and Inclusion: An International Journal, 19 (6), 549572.

Kramsch, C. (2013). Culture in foreign language teaching. Iranian Journal of Language Teaching Research, 1(1), 57-78.

Lazar, L. (2008). Recognising intercultural competence: What shows that I am interculturally competent? Pestalozzi programme and the intercultural cities project of the council of Europe/European commission and the European wergeland centre. Retrieved from

https://www.coe.int/t/dg4/education/p estalozzi/Source/Documentation/ICC Tool2014/ICToolGB.pdf

Liddicoat, A. J., \& Scarino, A. (2013). Intercultural language teaching and learning. West Sussex: WileyBlackwell.

Liddicoat, A. J., Papademetre, L., Scarino, A., \& Kohler, M. (2003).
Intercultural language learning. Australia: Commonwealth Department of Education, Science and Training.

Liddicoat A. J., \& Scarino, A. (2010). Eliciting the Intercultural in Foreign Language Education at School. In P. A. /Serc. L. (Ed.), Testing the Untestable in Language Education (pp. 52-73). Clevedon: Multilingual Matters.

Madya, S. (2013). Metodologi pembelajaran bahasa: Dari era prametode sampai era pasca-metode. Yogyakarta: UNY Press.

Morgana, R., \& Anshori, S. (2018). Indonesian EFL teachers' conceptualization of culture in the 21 st century EFL classroom. Suar Betang, 13 (2), 169-181. https://doi.org/Morgana, R., \& Anshori, S

Morganna, R., Sumardi, \& Tarjana, S. S. (2020). Tertiary English students' attitudes towards intercultural language learning. Indonesian Journal of Applied Linguistics, 9(7), 657-665.

https://doi.org/https://doi.org/10.1750 9/ ijal.v9i3.23216

Neculaesei, A. N. (2015). Culture and gender role differences. CrossCultural Management Journal, 17 (7), 31-35.

Sun, W. (2013). How to Cultivate Intercultural Communication Competence of Non-English Major Students. In Theory and Practice in Language Studies (pp. 2245-2249).

Vidiyanti, M. O., \& Yulianto, B. (2019). Pendidikan multikulturalisme dalam puisi digital Gorontalo tanah berdaulat karya Jamal Rahman Iroth: Kajian mosaic analogy Berkson. Telaga Bahasa, 7 (2), 173-180.

Wesarat, P. O., Majid, A. H., \& Sharif, M. Y. (2016). A framework for assessing gender influence on career choice of undergraduate students in Thailand. 
Proceeding of BESSH, 16-21.

\section{APPENDIX}

1. Degree of IC Results

\begin{tabular}{|c|c|c|c|c|c|}
\hline \multicolumn{6}{|c|}{ Descriptive Statistics } \\
\hline & $\mathrm{N}$ & $\begin{array}{l}\text { Minim } \\
\text { um }\end{array}$ & $\begin{array}{c}\text { Maxim } \\
\text { um }\end{array}$ & $\begin{array}{c}\text { Mea } \\
\mathrm{n}\end{array}$ & $\begin{array}{c}\text { Std. } \\
\text { Deviati } \\
\text { on }\end{array}$ \\
\hline $\begin{array}{l}\text { Total_ } \\
\text { A }\end{array}$ & $\begin{array}{l}8 \\
8\end{array}$ & 24 & 38 & $\begin{array}{r}30.3 \\
2\end{array}$ & 3.004 \\
\hline $\begin{array}{l}\text { Total_ } \\
\mathrm{S} \\
\end{array}$ & $\begin{array}{l}8 \\
8 \\
\end{array}$ & 44 & 106 & $\begin{array}{r}88.0 \\
7 \\
\end{array}$ & 9.457 \\
\hline $\begin{array}{l}\text { Total_ } \\
\mathrm{K}\end{array}$ & $\begin{array}{l}8 \\
8 \\
\end{array}$ & 14 & 50 & $\begin{array}{r}37.2 \\
8 \\
\end{array}$ & 6.259 \\
\hline $\begin{array}{l}\text { Total_ } \\
\text { IC }\end{array}$ & $\begin{array}{l}8 \\
8 \\
\end{array}$ & 82 & 191 & $\begin{array}{r}155 . \\
67 \\
\end{array}$ & 15.924 \\
\hline $\begin{array}{l}\text { Valid } \\
\mathrm{N} \\
\text { (listwi } \\
\text { se) }\end{array}$ & $\begin{array}{l}8 \\
8\end{array}$ & & & & \\
\hline
\end{tabular}

